\title{
Perspective
}

\section{Causes of Phenotypic Variability and Disabilities after Prenatal Viral Infections}

\author{
Youssef A. Kousa ${ }^{1,2, *(D)}$ and Reafa A. Hossain ${ }^{3}$ (D) \\ 1 Division of Neurology, Children's National Hospital, Washington, DC 20010, USA \\ 2 Department of Genomics and Precision Medicine, School of Medicine and Health Sciences, The George \\ Washington University, Washington, DC 20052, USA \\ 3 Structural Virology Section, Laboratory of Infectious Diseases, National Institute of Allergy and Infectious \\ Diseases, National Institute of Health, Bethesda, MD 20892, USA; hossaira@dukes.jmu.edu \\ * Correspondence: ykousa@cnmc.org
}

Citation: Kousa, Y.A.; Hossain, R.A. Causes of Phenotypic Variability and Disabilities after Prenatal Viral Infections. Trop. Med. Infect. Dis. 2021, 6, 95. https://doi.org/10.3390/ tropicalmed6020095

Academic Editor: John Frean

Received: 10 May 2021

Accepted: 29 May 2021

Published: 1 June 2021

Publisher's Note: MDPI stays neutral with regard to jurisdictional claims in published maps and institutional affiliations.

Copyright: (c) 2021 by the authors. Licensee MDPI, Basel, Switzerland. This article is an open access article distributed under the terms and conditions of the Creative Commons Attribution (CC BY) license (https:// creativecommons.org/licenses/by/ $4.0 /)$.

\begin{abstract}
Prenatal viral infection can lead to a spectrum of neurodevelopmental disabilities or fetal demise. These can include microencephaly, global developmental delay, intellectual disability, refractory epilepsy, deafness, retinal defects, and cortical-visual impairment. Each of these clinical conditions can occur on a semi-quantitative to continuous spectrum, from mild to severe disease, and often as a collective of phenotypes. Such serious outcomes result from viruses' overlapping neuropathology and hosts' common neuronal and gene regulatory response to infections. The etiology of variability in clinical outcomes is not yet clear, but it may be related to viral, host, vector, and/or environmental risk and protective factors that likely interact in multiple ways. In this perspective of the literature, we work toward understanding the causes of phenotypic variability after prenatal viral infections by highlighting key aspects of the viral lifecycle that can affect human disease, with special attention to the 2015 Zika pandemic. Therefore, this work offers important insights into how viral infections and environmental teratogens affect the prenatal brain, toward our ultimate goal of preventing neurodevelopmental disabilities.
\end{abstract}

Keywords: prenatal viral infections; Zika virus; flaviviruses; global child health; neurodevelopmental disabilities; brain development; phenotypic variability

\section{Introduction}

Prenatal infections are a leading cause of 2.6 million neonatal deaths globally each year. In addition, such infections increase the risk for preterm birth and contribute $11 \%$ of cerebral palsy risk [1-4]. In a series of 118 cases, prenatal infections were identified in 39\% of second-trimester deaths and accounted for $45 \%$ of abortions [5].

Parental viral infections are of greatest concern because they are often difficult to diagnose, and the developing brain is uniquely susceptible to severe injury [6,7]. Of significant note, prenatal viral infections tend to cause the same types of neuropathology and neurodevelopmental disorders in a clinical continuum that can include microencephaly, global developmental delay, intellectual disability, refractory epilepsy, deafness, retinal defects, and cortical-visual impairment (see Table for selected prenatal viral infections and a summary of their associated features and clinical outcomes [3-5,8-10]). In fact, while some classic features are pathognomonic, prenatal viral infections are almost clinically indistinguishable by neuroradiographic criteria or clinical outcomes alone [10] Serious clinical outcomes like these result from the viruses' overlapping neuropathology, on the one hand, and from the host's common neuronal and gene regulatory response to infections, on the other [6].

Despite the epidemiologic and clinical significance of this problem, no prenatal standards of care in treatment are available today, nor can virally induced prenatal brain injury yet be targeted for prevention. This reality calls for a deeper understanding of the 
corresponding neurobiology, which remains extremely limited, as a critical step toward preventing and addressing prenatal brain injury.

As a case in point, during the $2015 \mathrm{Zika}$ pandemic, prenatal viral infection was identified as the cause of congenital Zika syndrome (CZS), a clinical entity that can include severe microencephaly and a partially collapsed skull, among other specific features common to most prenatal viral infections (Table 1) [11]. In the past 5 years, prenatal Zika infection has been shown to cause a spectrum of neurodevelopmental disabilities [12,13]. Importantly, these features can occur in isolation or as a combination of phenotypes [12-16]. Studies are ongoing to determine all of the clinical and developmental manifestations of prenatal infection, but we already know that some infants can be severely or moderately affected while other infants appear to be completely unaffected at present.

Table 1. Prenatal viral infections lead to overlapping neuropathology and neurodevelopmental disabilities.

\begin{tabular}{|c|c|c|c|c|c|c|c|}
\hline & $\mathrm{CMV}^{1}$ & HIV & HSV & $\mathrm{LCMV}^{2}$ & Rubella & $\mathrm{VZV}^{3}$ & Zika \\
\hline Calcifications & $\checkmark$ & $\checkmark$ & $\checkmark$ & $\checkmark$ & $\checkmark$ & & $\checkmark$ \\
\hline $\begin{array}{l}\text { Cerebral Palsy/ } \\
\text { Motor Delay }\end{array}$ & $\boldsymbol{V}$ & $\boldsymbol{\nu}$ & $\boldsymbol{V}$ & $\boldsymbol{\nu}$ & $\boldsymbol{V}$ & & $\checkmark$ \\
\hline Cerebellar Hypoplasia & $\checkmark$ & & & $\checkmark$ & & & $\checkmark$ \\
\hline Chorioretinitis/Blindness & $\checkmark$ & $\checkmark$ & $\checkmark$ & $\checkmark$ & $\checkmark$ & $\checkmark$ & $\checkmark$ \\
\hline Cortical Malformation & $\checkmark$ & & $\checkmark$ & $\checkmark$ & & $\checkmark$ & $\checkmark$ \\
\hline Epilepsy/Seizures & $\checkmark$ & & $\checkmark$ & $\checkmark$ & $\checkmark$ & $\checkmark$ & $\checkmark$ \\
\hline Hearing Loss & $\checkmark$ & $\checkmark$ & & & $\checkmark$ & & $\checkmark$ \\
\hline $\begin{array}{c}\text { Intellectual/ } \\
\text { Learning Disability }\end{array}$ & $\boldsymbol{V}$ & $\boldsymbol{\nu}$ & $\boldsymbol{V}$ & $\boldsymbol{V}$ & $\checkmark$ & $\checkmark$ & $\boldsymbol{V}$ \\
\hline $\begin{array}{l}\text { Intraventricular } \\
\text { Hemorrhage }\end{array}$ & & & & & & $\boldsymbol{\nu}$ & $\boldsymbol{V}$ \\
\hline Meningoencephalitis & $\checkmark$ & $\checkmark$ & $\checkmark$ & $\checkmark$ & $\checkmark$ & $\checkmark$ & $\checkmark$ \\
\hline Microcephaly & $\checkmark$ & $\checkmark$ & $\checkmark$ & $\checkmark$ & $\checkmark$ & $\checkmark$ & $\checkmark$ \\
\hline Myelination Disorder & & $\checkmark$ & & & $\checkmark$ & & $\checkmark$ \\
\hline Neuropathies & & & & & & & $\checkmark$ \\
\hline $\begin{array}{l}\text { Vasculopathy/ } \\
\text { Porencephaly }\end{array}$ & & $\boldsymbol{V}$ & & $\checkmark$ & $\checkmark$ & & $\checkmark$ \\
\hline $\begin{array}{l}\text { Ventriculomegaly/ } \\
\text { Hydrocephalus }\end{array}$ & $\boldsymbol{V}$ & & $\boldsymbol{V}$ & $\boldsymbol{\nu}$ & & & $\boldsymbol{V}$ \\
\hline
\end{tabular}

${ }^{1}$ Cytomegalovirus; ${ }^{2}$ Lymphocytic Choriomeningitis Virus; ${ }^{3}$ Varicella Zoster.

Variability in outcomes after prenatal viral infections suggests either a continuous phenotypic spectrum or discrete phenotypic clusters [7,11-15,17-21]. At this point, there is more evidence in support of discrete phenotypic clusters, but subtle quantitative effects may take longer to describe [12,13]. In either case, both models suggest quantitative phenotypic variability and differences in disease severity that may result from differences in the pathogen, vector, host, or environment or-more broadly—at any point in the virushost cycle (Figure 1). (While a normal distribution is represented here given populational tendencies for quantitative characteristics (e.g., head circumference, height, weight, IQ), a nonparametric distribution is also possible. At this point, there is not sufficient data to know for sure which model is more accurate.)

To consider the causes of phenotypic variability after prenatal Zika virus infection and to gain a greater understanding of other prenatal viral infections, it is important to review the viral transmission lifecycle because, in theory, each of these stages (or variables) can have a downstream effect on the infected fetus. Validation of disease modifiers may point to therapeutically exploitable pathways for treatment or prevention of prenatal brain injury. In this work, we will review possible or likely factors that may contribute risk or protection in brain injury and the evidence where available. Overall, more studies are needed to identify and evaluate qualitative and quantitative disease modifiers and systematically deconstruct the causes of disease outcomes to identify those factors most amenable to public health or medical intervention. 


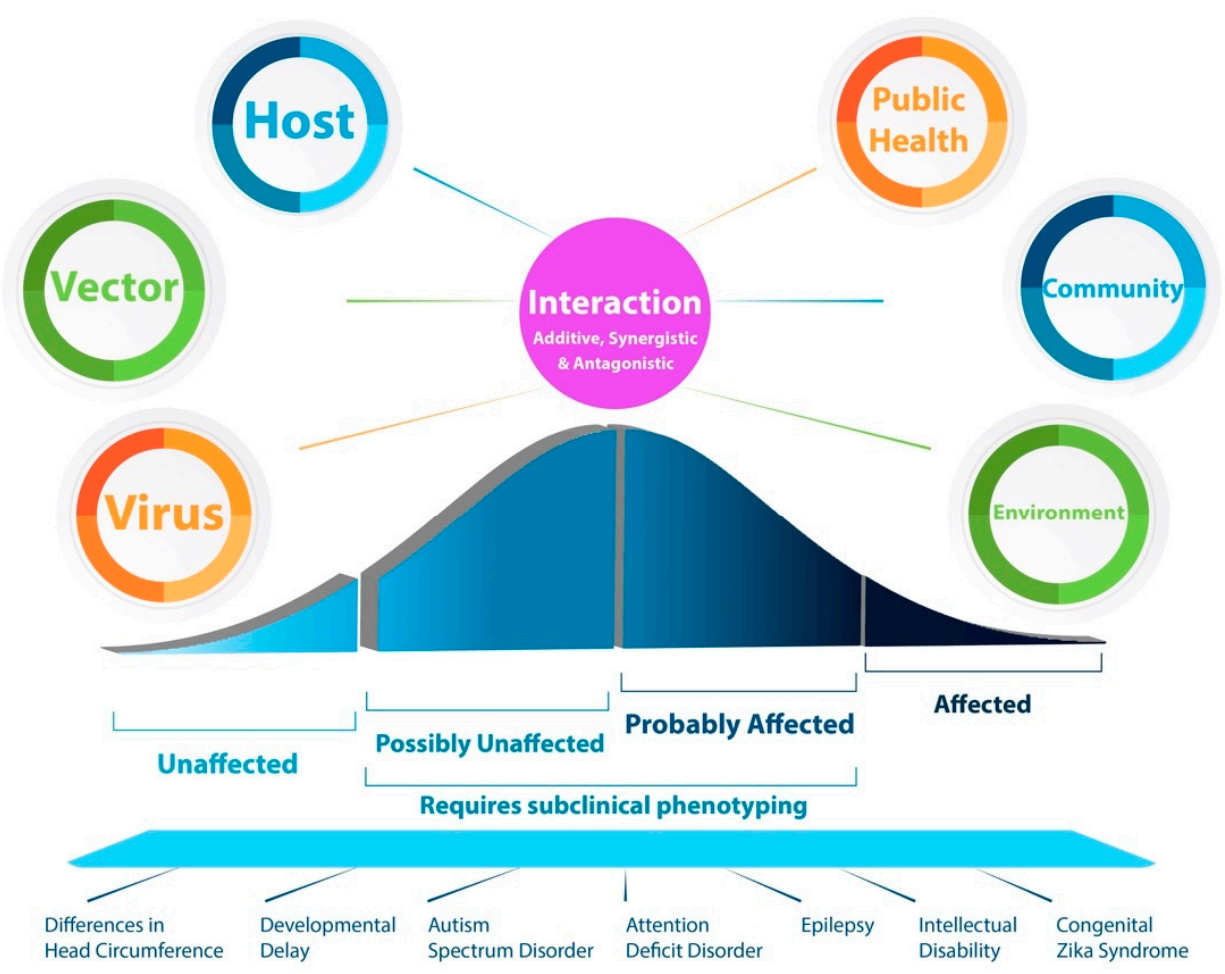

Figure 1. Interaction between possible disease modifiers and the spectrum of outcomes associated with prenatal viral infections. Various factors, including viral, vector, host, medical, community, and environment, may contribute to the spectrum of neurodevelopmental disabilities seen after prenatal viral infection, including in the case of Zika virus. These, in-turn, may interact in additive, synergistic, or antagonistic ways, which are yet unclear. The resulting phenotypic spectrum includes infants who are unaffected, possibly unaffected, probably affected, or affected. Affected individuals are commonly identified in appropriate clinical care settings, but the majority of individuals who are affected will likely require subclinical phenotyping, which can include neuroimaging, serial neurodevelopmental follow-up, and quantitative morphometrics. The resulting end-phenotypes can include a range of neurodevelopmental disabilities, which may include quantitative differences in head circumference, developmental attainment, the risk for seizures or epilepsy, social skills, attention, and intellect. Importantly, congenital Zika syndrome is but one manifestation of prenatal viral infection.

\section{Zika-Mosquito-Host Cycle}

The Zika virus transmission cycle includes two parallel processes in nonhuman primates (Sylvatic) or humans (suburban-urban) that can interact or have crossover through the mosquito vector. In both cycles, the virus is carried to a host by a mosquito vector or by direct human to human transmission. This is followed by viremia and downstream effects on the host(s). Mosquitos take a blood meal from an infected host and are infected by the virus. The virus then sequesters in the salivary gland of the mosquito vector. During subsequent blood meals by the mosquito, viral particles are injected into the host from the mosquito's salivary glands. The cycle continues after viral infection of another host. Differences in the lifecycle that affect viremia, neurotropism, or viral pathogenicity, likely contribute to the clinical outcome of the infected fetus.

The following sections cover differences in the virus, mosquito vector, human host, and their context, including public health and medical infrastructure, local community, and broader environment that can affect disease outcome after prenatal viral infection (Figure 2). Because of the number of people who were infected and are affected and mobilization by national and international research centers and funders to study this global health problem [22,23], the 2015 Zika virus pandemic offers a unique opportunity to study causes 
of phenotypic variability after prenatal viral infection and other environmental teratogens that affect the developing human brain.

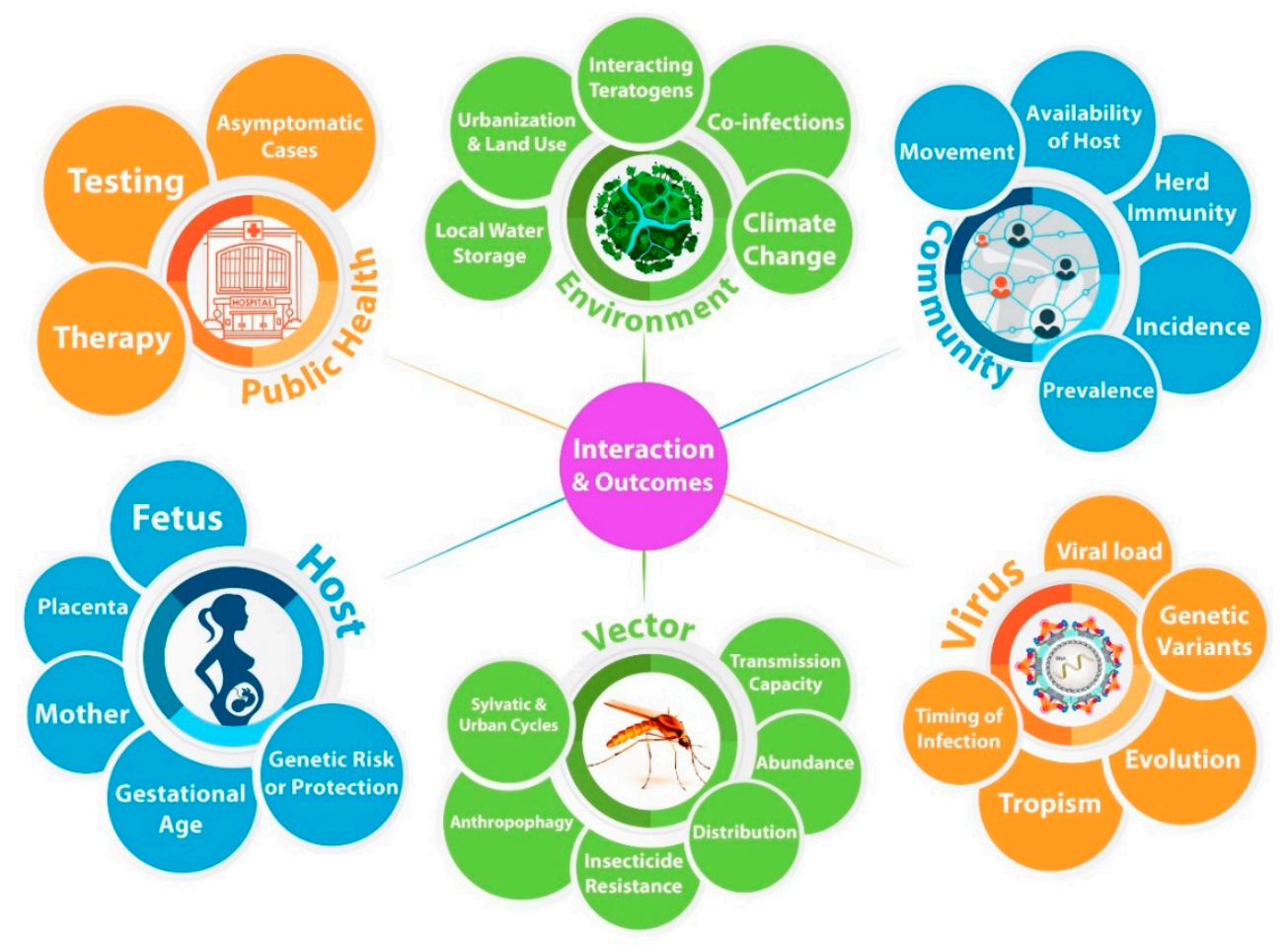

Figure 2. A model to consider possible modifiers of phenotypic variability in neurodevelopmental outcomes toward the long-term goal of prenatal precision therapies. There are likely primary drivers of neurodevelopmental disabilities. Moving clockwise, primary drivers include the environment, community, virus, vector, host, and public health efforts. Each primary driver is composed of highly interdependent factors. Epidemiologic, biomedical, and entomology research suggests the interaction among primary drivers can be additive, synergistic, or antagonistic. In multiple ways, the primary drivers are mutually interdependent in their outcomes. In order to develop personalized therapies to prevent neurodevelopmental disabilities, it is critically important to understand how (and when) these variables increase or decrease the risk of disease and to further delineate how they interact. In this way, personalized treatments or prevention strategies can be considered prenatally for viral infections, and other disorders affecting the developing brain.

\section{Virus}

Multiple streams of evidence strongly suggest that differences in the virus, including tissue tropism [24,25], viral strain [26], and evolution [27], contribute to phenotypic variability and disease severity in the infected fetus. First isolated from rhesus monkeys in the Zika forest of Uganda in 1947, Zika virus is phylogenetically categorized as a flavivirus [28]. This family of viruses includes many emerging human pathogens of clinical and public health significance, including Chikungunya, Dengue, yellow fever, and West Nile virus. Like other flavivirus, Zika virus has a small, single-stranded RNA genome, and it targets neural tissue [29] and non-neural tissue alike, including the placenta, testis, and uterus [4]. Unlike other flaviviruses, Zika can be transmitted between humans by exchange of bodily fluids and by sexual transmission [30-33]. In the postnatal brain, Zika leads to several infectious, para- and post-infectious, and inflammatory neurological disorders, affecting both the peripheral and central nervous systems and ranging from Guillain-Barre Syndrome to meningoencephalitis [34-38]. In mouse models, adapted viral strains result in similar developmental defects with prenatal [39-52] or postnatal infection $[24,53]$. 


\section{Viral Evolution Likely Contributed to Pathogenicity}

Mutations and evolution in the Zika viral genome are associated with increased viral pathogenicity. Sequence analyses have revealed three major genetic lineages of Zika virus; East African, West African, and Asian [26,54,55]. While genetically related, each viral strain evolves new characteristics that contribute to variable neuropathology. In one example, the nonstructural protein 1 (NS1) enhances viral prevalence in mosquitos and the mammalian population [54]. Analysis of the African lineages revealed a mutation at the 188th residue, from alanine to valine, which conferred secretability of the NS1 protein [54,56], and this may confer highly efficient enzootic and epizootic transmission $[54,57,58]$. Mutations in the nonstructural protein 3 (NS3) region, have been shown to increase viral replication in the mosquito, while decreasing replication in human cells [59]. Residues in the viral envelope (E) protein, including isoleucine 152, threonine 156, and histidine 158, have been implicated in the binding efficiency of Zika virus to host cells [60]. It is possible that viral strains co-evolved with their hosts and vectors, a theory that accounts for Zika's long-term potentiation and re-emergence throughout the 20th and 21st centuries [54].

Zika's unique ability to transfer directly between humans also suggests increased stability in bodily fluids, which may contribute to disease severity [25,61]. Cryogenic electron-microscopy of Zika incubated at different temperatures suggests high stability of viral particles at $40{ }^{\circ} \mathrm{C}$ in urine, saliva, or semen, in contrast to Dengue, which is not detected in these bodily fluids [61-65]. However, when studying the infectivity of Zika after incubation at $40{ }^{\circ} \mathrm{C}$, the half-life $(11.8 \mathrm{~h})$ was comparable to Dengue $(5.2 \mathrm{~h})$ and West Nile virus $(17.7 \mathrm{~h})$, suggesting that viral pathogenicity is not only related to stability $[62,66]$.

\section{Mosquito}

Flavivirus, including Zika, are transmitted to humans by Aedes mosquitoes, which have an expanding global distribution that now includes every continent and 41 of the 48 contiguous United States [28]. Zika virus is preferentially transmitted by some species of the Aedes mosquito, including A. aegypti, A. albopictus, A. hensilli, and A. polynesiensis [67] Similar to viral and host factors, differences in the Aedes mosquito can affect clinical outcomes [68] because they can affect the viral load that reaches the host. For instance, a recent study identified enhanced viral susceptibility in the evolution of a subspecies of A. aegypti aegypti, which invaded countries in the tropical belt. The change in the mosquito population was a major factor in the pathogenesis of Zika virus, and other flaviviruses [68] Combined with a preference to lay eggs in human-made containers [69], it appears that A. aegypti aegypti's abundance in South America compared to Africa contributed to disease risk during the pandemic [68]. Conversely, African species of the mosquito, A. ageypti formosus, appears to be more resistant to Zika virus [68]. A. aegypti aegypti also has an allelic variation in the Or4 odorant receptor gene that is linked to a preference for biting humans $[70,71]$. It is possible that increased mosquito susceptibility results from genetic drift, adaptation to human urbanization, and/or region-specific factors, including climate change and human genetic changes [71].

In the western Pacific, such as the Federated States of Micronesia (FSM) and Palau, a 2007 outbreak of Zika virus was brought to the islands by a mosquito [72,73]. Introduction of the mosquito, along with the lack of herd immunity, contributed to the pandemic in this region. In addition, intense air and sea traffic could introduce mosquito species into different geographic regions across the globe [72,73]. The density and type of endogenous mosquito populations can affect the ability of novel mosquito species to establish new territory [72]. Artificial and natural habitats could support further evolution of various mosquito species [72], an approach that is considered in limiting mosquito populations that contribute to human disease [74]. 


\section{Host}

\subsection{Gestational Age Confers Susceptible to Zika Pathogenesis}

Epidemiological data from multiple countries strongly suggests that viral infection during the first trimester of gestation is associated with the greatest risk of severe neurodevelopmental disorders, including microcephaly $[25,75]$ and other developmental abnormalities [76]. Consistently, Coutinho et al.'s prospective population-based study found a strong association between poor infant prognosis when mothers' were infected with Zika virus during the first trimester ( $<12$ weeks) of gestation [16]. These findings were corroborated by neuroimaging, which showed an eight times higher rate of brain abnormalities after first-trimester exposure compared to later in gestation. The risk of fetal anomalies was 14-fold higher [76].

\subsection{Phenotypic Variation: From Congenital Zika Syndrome to Mild, and Subclinical Developmental Delay}

In several recent studies, Zika-exposed children with normal clinical examinations and neuroimaging at birth went on to develop mild to moderate developmental delay and developmental disabilities $[12,13,76]$. Often, initially asymptotic infants had a developmental delay of 3-12 months of age. These findings included poor head growth or worsening developmental delay over time [77]. Prenatal Zika infection may also increase the risk for autism spectrum disorder $[77,78]$. Exposure to other viruses in the Flaviviridae family may also affect development, a factor that might be heightened when children are exposed to multiple related viruses $[16,77,79]$. Given this variability, physicians caring for patients with suspected exposure or those working in endemic areas should continue to closely evaluate head circumference and developmental attainment of prenatally exposed infants, even when infants are asymptomatic at birth [80]. A systematic approach is needed to assess the impact of Zika virus infection at specific gestational ages so that physicians, parents, and local resources can guide care and therapy for children with increased risk for delay or disability [16].

\subsection{Host Genetic Modifiers after Prenatal Zika Infection}

Powered by genetics and genomics, human susceptibility to infections is a subject of increasing interest over the past 60 years [81]. Among the first of these studies, a higher concordance rate of tuberculosis infection was identified in monozygotic twins compared to dizygotic twins [82], suggesting host genetic factors can contribute to increased susceptibility to infections. More recently, genetic susceptibility was identified for Plasmodium falciparum, a mosquito-borne unicellular protozoan that leads to malaria in childhood [83,84]; for HIV, a sexually transmitted RNA virus that can be congenitally acquired $[10,85,86]$, and for Dengue, an emerging mosquito-borne flavivirus with a singlestranded RNA genome [87]. Zika is similar to these infectious agents because it is a mosquito-borne, prenatally acquired, and an RNA virus.

Interestingly, while many of these genetic modifiers confer risk [83,85], others factors confer protection $[81,87-89]$. The human genetic architecture of risk and protection is best characterized for HIV, where host genetic factors can affect viral load, disease progression, viral clearance, viral control, and chronic infection [85,88-98]. Mapping these genes illuminates critical genetic and cellular pathways that constitute the host response to viral infections and provides insights into creating preventative and therapeutic strategies and, ultimately, into producing rationale vaccine candidates.

Looking at it from the host's vantage point, there are three [99] important Zika targets and thus potential host modifiers of prenatal brain injury: the mother $[16,100,101]$, placenta [102], and fetus [103]. For example, identical twins have similar types of brain injury, whereas, fraternal twins have different levels of brain injury [103,104]. This suggests genetic susceptibility in the fetus can affect neurodevelopmental outcomes [53,104]. As an example, human neurodevelopmental protein Musashi 1 affects Zika replication [105], and differences in mTOR signaling correlate with phenotypic differences among discordant 
dizygotic twins [103]. In addition to genetic differences between infants, different human populations appear to be affected differently as well $[7,18,55]$. This further suggests that genetic differences between populations can also contribute to risk.

In addition to neurodevelopmental gene expression, differences in host immune response, including T-cells, immunoglobulin, and mucin (TIM1) phosphatidylserine transmembrane receptors, have also been implicated in Zika-binding to a wider range of host tissues compared to Dengue [25,106]. TIM1 is also present in the human placenta, which might be a mechanism for placental infection, and could be a therapeutic target to prevent fetal infection $[25,106]$

6.4. Differences in Head Circumference after Prenatal Zika Infection Offers a Unique Opportunity to Study a Variable Clinical and Quantitative Phenotype with Impact on Human Development

Of the phenotypes associated with Zika virus, microcephaly and microencephaly were among the first to be recognized [107-111]. According to the CDC, microcephaly affects one in every 800 to 5000 infants and is defined as head circumference less than two standard deviations from the mean, for age and sex. In contrast, microencephaly refers to abnormalities in the brain tissue itself, defined as a brain weight two standard deviations below the mean. Microencephaly is an important medical problem to consider because it is associated with intractable epilepsy, cerebral palsy, global developmental delay, intellectual disability, and ophthalmologic disorders [112]. Studies on microencephaly are harder to perform because they often require neuroimaging, whereas microcephaly is evaluated routinely by measuring head circumference. Microcephaly and microencephaly often, but do not always, correlate directly.

Like many human conditions, microcephaly is genetically complex, which means both genetic and environmental factors contribute to risk [108]. Only 12 genetic loci are known in congenital microcephaly [113], but many more genetic syndromes or forms of brain injury can include microcephaly as a phenotypic component [114]. In addition to congenital presentations, microcephaly can also result from poor head growth over time (postnatal onset) $[108,112]$. The drivers of microencephaly include disorders in neurogenesis, neuronal cell death, or defects in neuronal maturation [108]. In addition to genetic causes, multiple environmental factors can result in microencephaly from brain injury (acquired), including malnutrition and other infections $[10,108,115]$.

Interestingly, Zika is unique among infectious etiologies because it can lead to both congenital and postnatal onset microencephaly [116-119]. As a quantitative human trait, differences in head circumference can predict developmental attainment after Zika virus infection [12]. Therefore, the Zika pandemic offers a unique opportunity to study how environmental infectious pathogens, maternal-placental-fetal neuroimmune activation, and genetic modifiers affect postnatal human developmental attainment.

\section{Public Health, Community, and Environmental Factors}

\subsection{Public Health and Medical Considerations}

To date, as with other prenatal viral infections, it is difficult to diagnose prenatal Zika infection because the symptoms are nonspecific, if they occur $[28,118]$. Furthermore, there are no approved therapies to treat prenatal Zika virus infection or to prevent its associated developmental disabilities when (or if) an infection is detected [120,121]. Efforts are ongoing to identify and test vaccine candidates and therapeutic modalities [122]. When an infant is affected, a systematic and integrated approach is needed to assess the total impact relative to the gestational age at exposure so that parents and physicians can anticipate care for children with brain injury [16].

\subsection{Impacts on Transmission}

Investigations into the 2007 outbreak on the Yap Islands found immature forms of Ae. aegypti, Ae. hensilli, Ae. lameliferus, Ae. maehleri, and Ae. vexans in water-holding containers such as tires, tarp, water barrels, water tanks, and animal pans with the highest pro- 
portion in tires [72,123]. In the case of Brazil, standing water, improper disposal of garbage, and densely populated areas constitute potent breeding grounds for Ae. Aegypti [56,124]. A similar situation was seen with Dengue in Thailand, which likely contributed to the number of people affected and disease severity by impacting the overall viral load in the host $[56,125,126]$. Cumulatively, there is an increased risk of transmission, especially in urban populations where Aedes proliferation, and in turn viral load, is only mitigated by human behavior $[55,56]$. Other environmental factors include temperature, relative humidity, annual rainfall, and exposure to other teratogens.

\subsection{Interventions to Combat Vector Density}

It may be possible to reduce mosquito density by safely storing still water or disposing of artificial water containers, thus reducing mosquito access to breeding grounds. Pyriproxyfen can be used to prevent mosquito maturation into the adult form and allows predators to consume the larvae, overall decreasing the mosquito population [127]. Fumigation techniques and insecticides are important to consider, but their impact on the environment and pregnancy is unknown. Recent promising efforts have focused on using Wolbachia (a bacteria that infects mosquitos and blocks their viral infection) to reduce the transmission of mosquito-borne viruses [74].

\subsection{Socioeconomic Factors as Drivers and Modifiers of Clinical Outcomes}

Multiple studies have identified socioeconomic drivers for neurodevelopmental disabilities. For instance, higher maternal education reduced the risk of microcephaly prior to the pandemic in Brazil [128,129]. Further, lower household income and higher crowding was a risk factor for microcephaly [56,129]. Co-occurring health risks, such as malnutrition, increase the risk to the fetus [129]. Similar socioeconomic health modifiers should be considered and modeled in more developmental diseases [128]. Local efforts, for example, educating lower income households on Zika, can increase health-seeking behavior in socially marginalized groups and may decrease disease burden in future pandemics $[129,130]$.

\subsection{Global Climate Change}

Global climate change may also increase the incidence of prenatal viral infection [131]. Previous modeling of Aedes-borne pathogens, such as Dengue, suggests that climate change increases the growth rate of Aedes, and in turn Zika virus, by lowering the outbreak threshold $[124,132]$. Temperature differences may produce a larger population of Aedes species, and increase exposure to potential virus-carrying vectors [132]. While considering various socioeconomic scenarios, approximately 1.3 billion new people are predicted to shift into geographic regions with favorable conditions for Zika and other viral infections [131]. Along with temperature changes, and the expected increase in vector density, there is a higher risk for local transmission in Europe and North America [132]. Though modeling is heavily dependent on multiple factors, these insights can be used to guide preliminary responses in case of a future outbreak [132].

\section{A Conclusion and Perspective toward Understanding Phenotypic Variability after Prenatal Viral Infections}

Causes of phenotypic variability after a prenatal viral infection are emerging but are as yet unclear (Figure 1). Furthermore, their relative contributions (and their interaction) to risk or protection in disease are unknown. Recent studies suggest that some of these factors can include differences in the virus, vector (mosquito), host (which includes the mother, placenta, and fetus), medical care (including early diagnosis and treatment), local community, and environment. Each of these factors might interact with in additive, synergistic, or antagonistic ways that affect the development of the central nervous system. Clinical and epidemiologic data shows a phenotypic spectrum of neurodevelopmental disabilities after prenatal viral infection. In fact, while some individuals are either unaffected or affected, the likely majority of individuals may be affected but require deep clinical (or subclinical) phenotyping over time to uncover the full impact based on recent studies [12,13]. Helpful 
phenotyping strategies can include neuroimaging, morphometrics, and long-term neurodevelopmental evaluations. These types of evaluations are often limited in low- and middle-income countries, which likely contributes to a systemic ascertainment bias for the number of affected individuals.

In turn, each discrete clinical problem associated with prenatal infection (microencephaly, developmental delay, autism, intellectual disability) than have a phenotypic spectrum of their own, which is either semi-quantitative or continuous. For example, an affected infant can have autism that is mild, moderate, or severe (semi-quantitative). Further still, each of these phenotypes may occur in isolation or in tandem or as part of a spectrum of disorders that result from prenatal brain injury.

Identifying these factors, and modeling their relative contributions, is critically important in understanding viral neurobiology in the parental brain and preventing neurodevelopmental disabilities. With this model in mind, it might be possible to identify pharmacologic therapies or risk mitigation strategies for pregnant women and their future infants. Such work could help us fully realize the long-term goal of prenatal precision medicine toward the prevention or treatment of neurodevelopmental disabilities (Figure 2), for Zika and beyond.

Author Contributions: Y.A.K. devised the project, the main conceptual ideas, and proof outline, designed and created the table and figures, and wrote and edited the manuscript. With Y.A.K.'s mentorship and oversight, R.A.H. contributed to literature review and wrote sections of the manuscript. Both Y.A.K. and R.A.H. contributed to the final manuscript. All authors have read and agreed to the published version of the manuscript.

Funding: This research was funded by CDC grant number SC-2020-3045, and by the Child Neurology Society and Foundation PERF Shields Research Grant FP4971.

Conflicts of Interest: The authors declare no conflict of interest.

\section{References}

1. Khan, A.M.; Morris, S.K.; Bhutta, Z.A. Neonatal and Perinatal Infections. Pediatr. Clin. N. Am. 2017, 64, 785-798. [CrossRef]

2. Wu, Y.W.; Escobar, G.J.; Grether, J.K.; Croen, L.A.; Greene, J.D.; Newman, T.B. Chorioamnionitis and cerebral palsy in term and near-term infants. JAMA 2003, 290, 2677-2684. [CrossRef] [PubMed]

3. Lynch, L.; Ghidini, A. Perinatal infections. Curr. Opin. Obstet. Gynecol. 1993, 5, 24-32. [CrossRef] [PubMed]

4. Edwards, A.D.; Tan, S. Perinatal infections, prematurity and brain injury. Curr. Opin. Pediatr. 2006, 18, 119-124. [CrossRef] [PubMed]

5. Rudbeck Roge, H.; Henriques, U. Fetal and perinatal infections. A consecutive study. Pathol. Res. Pract. 1992, 188, 135-140. [CrossRef]

6. $\quad$ Ludlow, M.; Kortekaas, J.; Herden, C.; Hoffmann, B.; Tappe, D.; Trebst, C.; Griffin, D.E.; Brindle, H.E.; Solomon, T.; Brown, A.S.; et al. Neurotropic virus infections as the cause of immediate and delayed neuropathology. Acta Neuropathol. 2016, 131, 159-184. [CrossRef]

7. $\quad$ Brasil, P.; Pereira, J.P., Jr.; Moreira, M.E.; Ribeiro Nogueira, R.M.; Damasceno, L.; Wakimoto, M.; Rabello, R.S.; Valderramos, S.G.; Halai, U.A.; Salles, T.S.; et al. Zika Virus Infection in Pregnant Women in Rio de Janeiro. N. Engl. J. Med. 2016, 375, $2321-2334$. [CrossRef] [PubMed]

8. Nahmias, A.J.; Walls, K.W.; Stewart, J.A.; Herrmann, K.L.; Flynt, W.J., Jr. The ToRCH complex-perinatal infections associated with toxoplasma and rubella, cytomegol- and herpes simplex viruses. Pediatric Res. 1971, 405-406. [CrossRef]

9. Ford-Jones, E.L. An approach to the diagnosis of congenital infections. Paediatr. Child. Health 1999, 4, 109-112. [CrossRef]

10. Neu, N.; Duchon, J.; Zachariah, P. TORCH infections. Clin. Perinatol. 2015, 42, 77-103. [CrossRef]

11. Moore, C.A.; Staples, J.E.; Dobyns, W.B.; Pessoa, A.; Ventura, C.V.; Fonseca, E.B.; Ribeiro, E.M.; Ventura, L.O.; Neto, N.N.; Arena, J.F.; et al. Characterizing the Pattern of Anomalies in Congenital Zika Syndrome for Pediatric Clinicians. JAMA Pediatrics 2017, 171, 288-295. [CrossRef]

12. Cranston, J.S.; Tiene, S.F.; Nielsen-Saines, K.; Vasconcelos, Z.; Pone, M.V.; Pone, S.; Zin, A.; Salles, T.S.; Pereira, J.P., Jr.; Orofino, D.; et al. Association Between Antenatal Exposure to Zika Virus and Anatomical and Neurodevelopmental Abnormalities in Children. JAMA Netw. Open 2020, 3, e209303. [CrossRef]

13. Mulkey, S.B.; Arroyave-Wessel, M.; Peyton, C.; Bulas, D.I.; Fourzali, Y.; Jiang, J.; Russo, S.; McCarter, R.; Msall, M.E.; du Plessis, A.J.; et al. Neurodevelopmental Abnormalities in Children With In Utero Zika Virus Exposure Without Congenital Zika Syndrome. JAMA Pediatrics 2020, 174, 269-276. [CrossRef] [PubMed] 
14. Mulkey, S.B. Head Circumference as a Measure of In Utero Zika Virus Exposure and Outcomes. JAMA Netw. Open 2020, 3, e209461. [CrossRef]

15. Mulkey, S.B.; DeBiasi, R.L. Do Not Judge a Book by Its Cover: Critical Need for Longitudinal Neurodevelopmental Assessment of In Utero Zika-Exposed Children. Am. J. Trop. Med. Hyg. 2020, 102, 913-914. [CrossRef]

16. Coutinho, C.M.; Neg, S.; Araujo, D.; Teixeira, S.R.; Amaral, F.R.; Moro, M.; Fernandes, J.; da Motta, M.; Negrini, B.; Caldas, C.; et al. Early maternal Zika infection predicts severe neonatal neurological damage: Results from the prospective Natural History of Zika Virus Infection in Gestation cohort study. BJOG 2020. [CrossRef]

17. Cuevas, E.L.; Tong, V.T.; Rozo, N.; Valencia, D.; Pacheco, O.; Gilboa, S.M.; Mercado, M.; Renquist, C.M.; Gonzalez, M.; Ailes, E.C.; et al. Preliminary Report of Microcephaly Potentially Associated with Zika Virus Infection During Pregnancy-Colombia, January-November 2016. MMWR Morb. Mortal. Wkly. Rep. 2016, 65, 1409-1413. [CrossRef] [PubMed]

18. Pacheco, O.; Beltran, M.; Nelson, C.A.; Valencia, D.; Tolosa, N.; Farr, S.L.; Padilla, A.V.; Tong, V.T.; Cuevas, E.L.; Espinosa-Bode, A.; et al. Zika Virus Disease in Colombia-Preliminary Report. N. Engl. J. Med. 2016. [CrossRef] [PubMed]

19. Hurtado-Villa, P.; Puerto, A.K.; Victoria, S.; Gracia, G.; Guasmayan, L.; Arce, P.; Alvarez, G.; Blandon, E.; Rengifo, N.; Holguin, J.A.; et al. Raised Frequency of Central Nervous System Malformations Related to Zika Virus Infection in Two Birth Defects Surveillance Systems in Bogota and Cali, Colombia. Pediatr. Infect. Dis. J. 2017. [CrossRef]

20. Jaenisch, T.; Rosenberger, K.D.; Brito, C.; Brady, O.; Brasil, P.; Marques, E.T. Risk of microcephaly after Zika virus infection in Brazil, 2015 to 2016. Bull. World Health Organ. 2017, 95, 191-198. [CrossRef] [PubMed]

21. Adachi, K.; Romero, T.; Nielsen-Saines, K.; Pone, S.; Aibe, M.; Barroso de Aguiar, E.; Sim, M.; Brasil, P.; Zin, A.; Tsui, I.; et al. Early Clinical Infancy Outcomes for Microcephaly and/or Small for Gestational Age Zika-Exposed Infants. Clin. Infect. Dis. 2020, 70, 2663-2672. [CrossRef] [PubMed]

22. Gonzalez, M.; Tong, V.T.; Rodriguez, H.; Valencia, D.; Acosta, J.; Honein, M.A.; Ospina, M.L.; Team, Z.E.N.S. Cohort Profile: Congenital Zika virus infection and child neurodevelopmental outcomes; Zika en Embarazadas y Ninos (ZEN) cohort study in Colombia. Epidemiol. Health 2020, e2020060. [CrossRef] [PubMed]

23. Lebov, J.F.; Arias, J.F.; Balmaseda, A.; Britt, W.; Cordero, J.F.; Galvao, L.A.; Garces, A.L.; Hambidge, K.M.; Harris, E.; Ko, A.; et al. International prospective observational cohort study of Zika in infants and pregnancy (ZIP study): Study protocol. BMC Pregnancy Childbirth 2019, 19, 282. [CrossRef]

24. Oh, Y.; Zhang, F.; Wang, Y.; Lee, E.M.; Choi, I.Y.; Lim, H.; Mirakhori, F.; Li, R.; Huang, L.; Xu, T.; et al. Zika virus directly infects peripheral neurons and induces cell death. Nat. Neurosci. 2017, 20, 1209-1212. [CrossRef] [PubMed]

25. Miner, J.J.; Diamond, M.S. Zika Virus Pathogenesis and Tissue Tropism. Cell Host Microbe 2017, 21, 134-142. [CrossRef]

26. Musso, D.; Ko, A.I.; Baud, D. Zika Virus Infection-After the Pandemic. N. Engl. J. Med. 2019, 381, 1444-1457. [CrossRef]

27. Yuan, L.; Huang, X.Y.; Liu, Z.Y.; Zhang, F.; Zhu, X.L.; Yu, J.Y.; Ji, X.; Xu, Y.P.; Li, G.; Li, C.; et al. A single mutation in the prM protein of Zika virus contributes to fetal microcephaly. Science 2017. [CrossRef]

28. Petersen, L.R.; Jamieson, D.J.; Powers, A.M.; Honein, M.A. Zika Virus. N. Engl. J. Med. 2016, 374, 1552-1563. [CrossRef]

29. Ho, C.Y.; Castillo, N.; Encinales, L.; Porras, A.; Mendoza, A.R.; Lynch, R.; Nemirovsky, A.; Mantus, G.; DeBiasi, R.L.; Bethony, J.M.; et al. Second-trimester Ultrasound and Neuropathologic Findings in Congenital Zika Virus Infection. Pediatr. Infect. Dis. J. 2018, 37, 1290-1293. [CrossRef]

30. Miner, J.J.; Sene, A.; Richner, J.M.; Smith, A.M.; Santeford, A.; Ban, N.; Weger-Lucarelli, J.; Manzella, F.; Ruckert, C.; Govero, J.; et al. Zika Virus Infection in Mice Causes Panuveitis with Shedding of Virus in Tears. Cell Rep. 2016, 16, 3208-3218. [CrossRef]

31. D'Ortenzio, E.; Matheron, S.; Yazdanpanah, Y.; de Lamballerie, X.; Hubert, B.; Piorkowski, G.; Maquart, M.; Descamps, D.; Damond, F.; Leparc-Goffart, I. Evidence of Sexual Transmission of Zika Virus. N. Engl. J. Med. 2016, 374, 2195-2198. [CrossRef] [PubMed]

32. Swaminathan, S.; Schlaberg, R.; Lewis, J.; Hanson, K.E.; Couturier, M.R. Fatal Zika Virus Infection with Secondary Nonsexual Transmission. N. Engl. J. Med. 2016, 375, 1907-1909. [CrossRef] [PubMed]

33. Newman, C.M.; Dudley, D.M.; Aliota, M.T.; Weiler, A.M.; Barry, G.L.; Mohns, M.S.; Breitbach, M.E.; Stewart, L.M.; Buechler, C.R.; Graham, M.E.; et al. Oropharyngeal mucosal transmission of Zika virus in rhesus macaques. Nat. Commun. 2017, 8, 169. [CrossRef] [PubMed]

34. Oehler, E.; Watrin, L.; Larre, P.; Leparc-Goffart, I.; Lastere, S.; Valour, F.; Baudouin, L.; Mallet, H.; Musso, D.; Ghawche, F. Zika virus infection complicated by Guillain-Barre syndrome-case report, French Polynesia, December 2013. Eurosurveillance 2014, 19. [CrossRef] [PubMed]

35. Pradhan, F.; Burns, J.D.; Agameya, A.; Patel, A.; Alfaqih, M.; Small, J.E.; Ooi, W. Case Report: Zika Virus Meningoencephalitis and Myelitis and Associated Magnetic Resonance Imaging Findings. Am. J. Trop. Med. Hyg. 2017, 97, 340-343. [CrossRef]

36. Joob, B.; Wiwanitkit, V. Zika Virus Meningoencephalitis. Mayo Clin. Proc. 2017, 92, 1313. [CrossRef]

37. Schwartzmann, P.V.; Ramalho, L.N.; Neder, L.; Vilar, F.C.; Ayub-Ferreira, S.M.; Romeiro, M.F.; Takayanagui, O.M.; Dos Santos, A.C.; Schmidt, A.; Figueiredo, L.T.; et al. Zika Virus Meningoencephalitis in an Immunocompromised Patient. Mayo Clin. Proc. 2017, 92, 460-466. [CrossRef]

38. Carteaux, G.; Maquart, M.; Bedet, A.; Contou, D.; Brugieres, P.; Fourati, S.; Cleret de Langavant, L.; de Broucker, T.; Brun-Buisson, C.; Leparc-Goffart, I.; et al. Zika Virus Associated with Meningoencephalitis. N. Engl. J. Med. 2016, 374, 1595-1596. [CrossRef]

39. Nowakowski, T.J.; Pollen, A.A.; Di Lullo, E.; Sandoval-Espinosa, C.; Bershteyn, M.; Kriegstein, A.R. Expression Analysis Highlights AXL as a Candidate Zika Virus Entry Receptor in Neural Stem Cells. CellStemCell 2016, 18, 591-596. [CrossRef] 
40. Lazear, H.M.; Govero, J.; Smith, A.M.; Platt, D.J.; Fernandez, E.; Miner, J.J.; Diamond, M.S. A Mouse Model of Zika Virus Pathogenesis. Cell Host Microbe 2016, 19, 720-730. [CrossRef] [PubMed]

41. Aliota, M.T.; Caine, E.A.; Walker, E.C.; Larkin, K.E.; Camacho, E.; Osorio, J.E. Characterization of Lethal Zika Virus Infection in AG129 Mice. PLoS Negl. Trop. Dis. 2016, 10, e0004682. [CrossRef]

42. Dang, J.; Tiwari, S.K.; Lichinchi, G.; Qin, Y.; Patil, V.S.; Eroshkin, A.M.; Rana, T.M. Zika Virus Depletes Neural Progenitors in Human Cerebral Organoids through Activation of the Innate Immune Receptor TLR3. CellStemCell 2016, 19, 258-265. [CrossRef] [PubMed]

43. Li, C.; Xu, D.; Ye, Q.; Hong, S.; Jiang, Y.; Liu, X.; Zhang, N.; Shi, L.; Qin, C.F.; Xu, Z. Zika Virus Disrupts Neural Progenitor Development and Leads to Microcephaly in Mice. CellStemCell 2016, 19, 120-126. [CrossRef]

44. Miner, J.J.; Cao, B.; Govero, J.; Smith, A.M.; Fernandez, E.; Cabrera, O.H.; Garber, C.; Noll, M.; Klein, R.S.; Noguchi, K.K.; et al Zika Virus Infection during Pregnancy in Mice Causes Placental Damage and Fetal Demise. Cell 2016, 165, 1081-1091. [CrossRef]

45. Malkki, H. CNS infections: Mouse studies confirm the link between Zika virus infection and microcephaly. Nat. Rev. Neurol. 2016, 12, 369. [CrossRef] [PubMed]

46. Kim, K.; Shresta, S. Neuroteratogenic Viruses and Lessons for Zika Virus Models. Trends Microbiol. 2016, 24, 622-636. [CrossRef]

47. Solomon, I.H.; Milner, D.A.; Folkerth, R.D. Neuropathology of Zika Virus Infection. J. Neuroinfect. Dis. 2016, 7. [CrossRef]

48. Yockey, L.J.; Varela, L.; Rakib, T.; Khoury-Hanold, W.; Fink, S.L.; Stutz, B.; Szigeti-Buck, K.; Van den Pol, A.; Lindenbach, B.D.; Horvath, T.L.; et al. Vaginal Exposure to Zika Virus during Pregnancy Leads to Fetal Brain Infection. Cell 2016, 166, 1247-1256.e4. [CrossRef] [PubMed]

49. Govero, J.; Esakky, P.; Scheaffer, S.M.; Fernandez, E.; Drury, A.; Platt, D.J.; Gorman, M.J.; Richner, J.M.; Caine, E.A.; Salazar, V.; et al. Zika virus infection damages the testes in mice. Nature 2016, 540, 438-442. [CrossRef]

50. Fernandes, N.C.; Nogueira, J.S.; Ressio, R.A.; Cirqueira, C.S.; Kimura, L.M.; Fernandes, K.R.; Cunha, M.S.; Souza, R.P.; Guerra, J.M. Experimental Zika virus infection induces spinal cord injury and encephalitis in newborn Swiss mice. Exp. Toxicol. Pathol. 2017, 69, 63-71. [CrossRef] [PubMed]

51. van den Pol, A.N.; Mao, G.; Yang, Y.; Ornaghi, S.; Davis, J.N. Zika Virus Targeting in the Developing Brain. J. Neurosci. 2017, 37, 2161-2175. [CrossRef]

52. Morrison, T.E.; Diamond, M.S. Animal Models of Zika Virus Infection, Pathogenesis, and Immunity. J. Virol. 2017, 91. [CrossRef]

53. Shao, Q.; Herrlinger, S.; Yang, S.L.; Lai, F.; Moore, J.M.; Brindley, M.A.; Chen, J.F. Zika virus infection disrupts neurovascular development and results in postnatal microcephaly with brain damage. Development 2016, 143, 4127-4136. [CrossRef]

54. Liu, Y.; Liu, J.; Du, S.; Shan, C.; Nie, K.; Zhang, R.; Li, X.F.; Zhang, R.; Wang, T.; Qin, C.F.; et al. Evolutionary enhancement of Zika virus infectivity in Aedes aegypti mosquitoes. Nature 2017, 545, 482-486. [CrossRef] [PubMed]

55. Weaver, S.C.; Costa, F.; Garcia-Blanco, M.A.; Ko, A.I.; Ribeiro, G.S.; Saade, G.; Shi, P.Y.; Vasilakis, N. Zika virus: History, emergence, biology, and prospects for control. Antiviral. Res. 2016, 130, 69-80. [CrossRef] [PubMed]

56. Campos, M.C.; Dombrowski, J.G.; Phelan, J.; Marinho, C.R.F.; Hibberd, M.; Clark, T.G.; Campino, S. Zika might not be acting alone: Using an ecological study approach to investigate potential co-acting risk factors for an unusual pattern of microcephaly in Brazil. PLoS ONE 2018, 13, e0201452. [CrossRef] [PubMed]

57. Diallo, D.; Sall, A.A.; Diagne, C.T.; Faye, O.; Faye, O.; Ba, Y.; Hanley, K.A.; Buenemann, M.; Weaver, S.C.; Diallo, M. Zika virus emergence in mosquitoes in southeastern Senegal, 2011. PLoS ONE 2014, 9, e109442. [CrossRef]

58. Buechler, C.R.; Bailey, A.L.; Weiler, A.M.; Barry, G.L.; Jasinska, A.J.; Freimer, N.B.; Apetrei, C.; Phillips-Conroy, J.E.; Jolly, C.J.; Rogers, J.; et al. Prevalence of Zika virus infection in wild African primates. BioRxiv 2016. [CrossRef]

59. Collette, N.M.; Lao, V.H.I.; Weilhammer, D.R.; Zingg, B.; Cohen, S.D.; Hwang, M.; Coffey, L.L.; Grady, S.L.; Zemla, A.T.; Borucki, M.K. Single Amino Acid Mutations Affect Zika Virus Replication In Vitro and Virulence In Vivo. Viruses 2020, 12, 1295. [CrossRef] [PubMed]

60. Limonta, D.; Hobman, T.C. Zika Virus and Host Interactions: From the Bench to the Bedside and Beyond. Cells 2020, 9, 2463. [CrossRef]

61. Cordeiro, C.N.; Bano, R.; Washington Cross, C.I.; Segars, J.H. Zika virus and assisted reproduction. Curr. Opin. Obstet. Gynecol. 2017, 29, 175-179. [CrossRef]

62. Sirohi, D.; Chen, Z.; Sun, L.; Klose, T.; Pierson, T.C.; Rossmann, M.G.; Kuhn, R.J. The 3.8 A resolution cryo-EM structure of Zika virus. Science 2016, 352, 467-470. [CrossRef]

63. Mansuy, J.M.; Dutertre, M.; Mengelle, C.; Fourcade, C.; Marchou, B.; Delobel, P.; Izopet, J.; Martin-Blondel, G. Zika virus: High infectious viral load in semen, a new sexually transmitted pathogen? Lancet Infect. Dis. 2016, 16. [CrossRef]

64. Gourinat, A.C.; O'Connor, O.; Calvez, E.; Goarant, C.; Dupont-Rouzeyrol, M. Detection of Zika virus in urine. Emerg. Infect. Dis. 2015, 21, 84-86. [CrossRef]

65. Nunez, A.I.; Talavera, S.; Birnberg, L.; Rivas, R.; Pujol, N.; Verdun, M.; Aranda, C.; Berdugo, M.; Busquets, N. Evidence of Zika virus horizontal and vertical transmission in Aedes albopictus from Spain but not infectious virus in saliva of the progeny. Emerg. Microbes. Infect. 2020, 1-22. [CrossRef]

66. Kostyuchenko, V.A.; Lim, E.X.; Zhang, S.; Fibriansah, G.; Ng, T.S.; Ooi, J.S.; Shi, J.; Lok, S.M. Structure of the thermally stable Zika virus. Nature 2016, 533, 425-428. [CrossRef] [PubMed]

67. Du, S.; Liu, Y.; Liu, J.; Zhao, J.; Champagne, C.; Tong, L.; Zhang, R.; Zhang, F.; Qin, C.F.; Ma, P.; et al. Aedes mosquitoes acquire and transmit Zika virus by breeding in contaminated aquatic environments. Nat. Commun. 2019, 10, 1324. [CrossRef] [PubMed] 
68. Aubry, F.; Dabo, S.; Manet, C.; Filipovic, I.; Rose, N.H.; Miot, E.F.; Martynow, D.; Baidaliuk, A.; Merkling, S.H.; Dickson, L.B.; et al. Enhanced Zika virus susceptibility of globally invasive Aedes aegypti populations. Science 2020, 370, 991-996. [CrossRef]

69. Brady, O.J.; Hay, S.I. The Global Expansion of Dengue: How Aedes aegypti Mosquitoes Enabled the First Pandemic Arbovirus. Annu. Rev. Entomol. 2020, 65, 191-208. [CrossRef] [PubMed]

70. McBride, C.S.; Baier, F.; Omondi, A.B.; Spitzer, S.A.; Lutomiah, J.; Sang, R.; Ignell, R.; Vosshall, L.B. Evolution of mosquito preference for humans linked to an odorant receptor. Nature 2014, 515, 222-227. [CrossRef] [PubMed]

71. Main, B.J.; Lee, Y.; Ferguson, H.M.; Kreppel, K.S.; Kihonda, A.; Govella, N.J.; Collier, T.C.; Cornel, A.J.; Eskin, E.; Kang, E.Y.; et al. The Genetic Basis of Host Preference and Resting Behavior in the Major African Malaria Vector, Anopheles arabiensis. PLoS Genet. 2016, 12, e1006303. [CrossRef] [PubMed]

72. Ledermann, J.P.; Guillaumot, L.; Yug, L.; Saweyog, S.C.; Tided, M.; Machieng, P.; Pretrick, M.; Marfel, M.; Griggs, A.; Bel, M.; et al. Aedes hensilli as a potential vector of Chikungunya and Zika viruses. PLoS Negl. Trop. Dis. 2014, 8, e3188. [CrossRef]

73. Lambrechts, L.; Scott, T.W.; Gubler, D.J. Consequences of the expanding global distribution of Aedes albopictus for dengue virus transmission. PLoS Negl. Trop. Dis. 2010, 4, e646. [CrossRef] [PubMed]

74. Ford, S.A.; Allen, S.L.; Ohm, J.R.; Sigle, L.T.; Sebastian, A.; Albert, I.; Chenoweth, S.F.; McGraw, E.A. Selection on Aedes aegypti alters Wolbachia-mediated dengue virus blocking and fitness. Nat. Microbiol. 2019, 4, 1832-1839. [CrossRef] [PubMed]

75. Schutte, B.C.; Sander, A.; Malik, M.; Murray, J.C. Refinement of the Van der Woude gene location and construction of a 3.5-Mb YAC contig and STS map spanning the critical region in 1q32-q41. Genomics 1996, 36, 507-514. [CrossRef]

76. Pool, K.L.; Adachi, K.; Karnezis, S.; Salamon, N.; Romero, T.; Nielsen-Saines, K.; Pone, S.; Boechat, M.; Aibe, M.; Gomes da Silva, T.; et al. Association Between Neonatal Neuroimaging and Clinical Outcomes in Zika-Exposed Infants From Rio de Janeiro, Brazil. JAMA Netw. Open 2019, 2, e198124. [CrossRef]

77. Abtibol-Bernardino, M.R.; de Almeida Peixoto, L.F.A.; de Oliveira, G.A.; de Almeida, T.F.; Rodrigues, G.R.I.; Otani, R.H.; Soares Chaves, B.C.; de Souza Rodrigues, C.; de Andrade, A.; de Fatima Redivo, E.; et al. Neurological Findings in Children without Congenital Microcephaly Exposed to Zika Virus in Utero: A Case Series Study. Viruses 2020, 12, 1335. [CrossRef]

78. Vianna, R.A.O.; Rua, E.C.; Fernandes, A.R.; Dos Santos, T.C.S.; Dalcastel, L.A.B.; Dos Santos, M.L.B.; de Paula, P.D.S.; de Carvalho, F.R.; Pache de Faria, A.O.; Almeida, P.L.; et al. Experience in diagnosing congenital Zika syndrome in Brazilian children born to asymptomatic mothers. Acta Trop. 2020, 206, 105438. [CrossRef]

79. Petzold, S.; Agbaria, N.; Deckert, A.; Dambach, P.; Winkler, V.; Drexler, J.F.; Horstick, O.; Jaenisch, T. Congenital abnormalities associated with Zika virus infection-Dengue as potential co-factor? A systematic review. PLoS Negl. Trop. Dis. 2021, 15, e0008984. [CrossRef]

80. Peçanha, P.M.; Gomes Junior, S.C.; Pone, S.M.; Pone, M.V.; Vasconcelos, Z.; Zin, A.; Vilibor, R.H.; Costa, R.P.; Meio, M.D.; Nielsen-Saines, K.; et al. Neurodevelopment of children exposed intra-uterus by Zika virus: A case series. PLoS ONE 2020, 15, e0229434. [CrossRef]

81. Chapman, S.J.; Hill, A.V. Human genetic susceptibility to infectious disease. Nat. Rev. Genet. 2012, 13, 175-188. [CrossRef]

82. Comstock, G.W. Tuberculosis in twins: A re-analysis of the Prophit survey. Am. Rev. Respir Dis. 1978, 117, 621-624. [CrossRef] [PubMed]

83. Driss, A.; Hibbert, J.M.; Wilson, N.O.; Iqbal, S.A.; Adamkiewicz, T.V.; Stiles, J.K. Genetic polymorphisms linked to susceptibility to malaria. Malar J. 2011, 10, 271. [CrossRef] [PubMed]

84. Hill, A.V. Genetic susceptibility to malaria and other infectious diseases: From the MHC to the whole genome. Parasitology 1996, 112, S75-S84. [CrossRef]

85. Fellay, J.; Shianna, K.V.; Ge, D.; Colombo, S.; Ledergerber, B.; Weale, M.; Zhang, K.; Gumbs, C.; Castagna, A.; Cossarizza, A.; et al. A whole-genome association study of major determinants for host control of HIV-1. Science 2007, 317, 944-947. [CrossRef] [PubMed]

86. International, H.I.V.C.S.; Pereyra, F.; Jia, X.; McLaren, P.J.; Telenti, A.; de Bakker, P.I.; Walker, B.D.; Ripke, S.; Brumme, C.J.; Pulit, S.L.; et al. The major genetic determinants of HIV-1 control affect HLA class I peptide presentation. Science 2010, 330, 1551-1557. [CrossRef]

87. Khor, C.C.; Chau, T.N.; Pang, J.; Davila, S.; Long, H.T.; Ong, R.T.; Dunstan, S.J.; Wills, B.; Farrar, J.; Van Tram, T.; et al. Genomewide association study identifies susceptibility loci for dengue shock syndrome at MICB and PLCE1. Nat. Genet. 2011, 43, 1139-1141. [CrossRef]

88. Jallow, M.; Teo, Y.Y.; Small, K.S.; Rockett, K.A.; Deloukas, P.; Clark, T.G.; Kivinen, K.; Bojang, K.A.; Conway, D.J.; Pinder, M.; et al. Genome-wide and fine-resolution association analysis of malaria in West Africa. Nat. Genet. 2009, 41, 657-665. [CrossRef]

89. Blanpain, C.; Libert, F.; Vassart, G.; Parmentier, M. CCR5 and HIV infection. Recept. Channels 2002, 8, 19-31. [CrossRef]

90. Fellay, J.; Ge, D.; Shianna, K.V.; Colombo, S.; Ledergerber, B.; Cirulli, E.T.; Urban, T.J.; Zhang, K.; Gumbs, C.E.; Smith, J.P.; et al. Common genetic variation and the control of HIV-1 in humans. PLoS Genet. 2009, 5, e1000791. [CrossRef]

91. Limou, S.; Coulonges, C.; Herbeck, J.T.; van Manen, D.; An, P.; Le Clerc, S.; Delaneau, O.; Diop, G.; Taing, L.; Montes, M.; et al. Multiple-cohort genetic association study reveals CXCR6 as a new chemokine receptor involved in long-term nonprogression to AIDS. J. Infect. Dis. 2010, 202, 908-915. [CrossRef] [PubMed]

92. Trachtenberg, E.; Bhattacharya, T.; Ladner, M.; Phair, J.; Erlich, H.; Wolinsky, S. The HLA-B/-C haplotype block contains major determinants for host control of HIV. Genes Immun. 2009, 10, 673-677. [CrossRef] [PubMed] 
93. Pelak, K.; Goldstein, D.B.; Walley, N.M.; Fellay, J.; Ge, D.; Shianna, K.V.; Gumbs, C.; Gao, X.; Maia, J.M.; Cronin, K.D.; et al. Host determinants of HIV-1 control in African Americans. J. Infect. Dis. 2010, 201, 1141-1149. [CrossRef] [PubMed]

94. Troyer, J.L.; Nelson, G.W.; Lautenberger, J.A.; Chinn, L.; McIntosh, C.; Johnson, R.C.; Sezgin, E.; Kessing, B.; Malasky, M.; Hendrickson, S.L.; et al. Genome-wide association study implicates PARD3B-based AIDS restriction. J. Infect. Dis. 2011, 203, 1491-1502. [CrossRef]

95. Limou, S.; Le Clerc, S.; Coulonges, C.; Carpentier, W.; Dina, C.; Delaneau, O.; Labib, T.; Taing, L.; Sladek, R.; Deveau, C.; et al. Genomewide association study of an AIDS-nonprogression cohort emphasizes the role played by HLA genes (ANRS Genomewide Association Study 02). J. Infect. Dis. 2009, 199, 419-426. [CrossRef] [PubMed]

96. Ciborowski, P.; Gendelman, H.E. Human immunodeficiency virus-mononuclear phagocyte interactions: Emerging avenues of biomarker discovery, modes of viral persistence and disease pathogenesis. Curr. HIV Res. 2006, 4, 279-291. [CrossRef]

97. Kraft-Terry, S.D.; Stothert, A.R.; Buch, S.; Gendelman, H.E. HIV-1 neuroimmunity in the era of antiretroviral therapy. Neurobiol. Dis. 2010, 37, 542-548. [CrossRef]

98. Sillman, B.; Woldstad, C.; McMillan, J.; Gendelman, H.E. Neuropathogenesis of human immunodeficiency virus infection. In Handbook of Clinical Neurology; Elsevier: Amsterdam, The Netherlands, 2018; Volume 152, pp. 21-40. [CrossRef]

99. Haig, D. Genetic conflicts in human pregnancy. Q. Rev. Biol. 1993, 68, 495-532. [CrossRef]

100. Paixao, E.S.; Leong, W.Y.; Rodrigues, L.C.; Wilder-Smith, A. Asymptomatic Prenatal Zika Virus Infection and Congenital Zika Syndrome. Open Forum. Infect. Dis. 2018, 5, ofy073. [CrossRef]

101. Santos, C.N.O.; Ribeiro, D.R.; Cardoso Alves, J.; Cazzaniga, R.A.; Magalhães, L.S.; de Souza, M.S.F.; Fonseca, A.B.L.; Bispo, A.J.B.; Porto, R.L.S.; Santos, C.A.d.; et al. Association Between Zika Virus Microcephaly in Newborns With the rs3775291 Variant in Toll-Like Receptor 3 and rs1799964 Variant at Tumor Necrosis Factor- $\alpha$ Gene. J. Infect. Dis. 2019, 220, 1797-1801. [CrossRef]

102. Mercado, M.; Daza, M.; Moore, C.A.; Valencia, D.; Rico, A.; Alvarez-Diaz, D.A.; Brault, A.C.; Fitzpatrick, K.; Mulkey, S.B. Discordant Clinical Outcomes in a Monozygotic Dichorionic-Diamniotic Twin Pregnancy with Probable Zika Virus Exposure. Case Report. Trop. Med. Infect. Dis. 2020, 5, 188. [CrossRef]

103. Caires-Junior, L.C.; Goulart, E.; Melo, U.S.; Araujo, B.H.S.; Alvizi, L.; Soares-Schanoski, A.; de Oliveira, D.F.; Kobayashi, G.S.; Griesi-Oliveira, K.; Musso, C.M.; et al. Discordant congenital Zika syndrome twins show differential in vitro viral susceptibility of neural progenitor cells. Nat. Commun. 2018, 9, 475. [CrossRef] [PubMed]

104. Linden, V.V.; Linden, H.V.J.; Leal, M.C.; Rolim, E.L.F.; Linden, A.V.; Aragao, M.; Brainer-Lima, A.M.; Cruz, D.; Ventura, L.O.; Florencio, T.L.T.; et al. Discordant clinical outcomes of congenital Zika virus infection in twin pregnancies. Arq. Neuropsiquiatr. 2017, 75, 381-386. [CrossRef] [PubMed]

105. Chavali, P.L.; Stojic, L.; Meredith, L.W.; Joseph, N.; Nahorski, M.S.; Sanford, T.J.; Sweeney, T.R.; Krishna, B.A.; Hosmillo, M.; Firth, A.E.; et al. Neurodevelopmental protein Musashi-1 interacts with the Zika genome and promotes viral replication. Science 2017, 357, 83-88. [CrossRef]

106. Hamel, R.; Dejarnac, O.; Wichit, S.; Ekchariyawat, P.; Neyret, A.; Luplertlop, N.; Perera-Lecoin, M.; Surasombatpattana, P.; Talignani, L.; Thomas, F.; et al. Biology of Zika Virus Infection in Human Skin Cells. J. Virol. 2015, 89, 8880-8896. [CrossRef]

107. Barreto, M.L.; Barral-Netto, M.; Stabeli, R.; Almeida-Filho, N.; Vasconcelos, P.F.C.; Teixeira, M.; Buss, P.; Gadelha, P.E. Zika virus and microcephaly in Brazil: A scientific agenda. Lancet 2016, 387, 919-921. [CrossRef]

108. Devakumar, D.; Bamford, A.; Ferreira, M.U.; Broad, J.; Rosch, R.E.; Groce, N.; Breuer, J.; Cardoso, M.A.; Copp, A.J.; Alexandre, P.; et al. Infectious causes of microcephaly: Epidemiology, pathogenesis, diagnosis, and management. Lancet Infect. Dis. 2017. [CrossRef]

109. Graham, K.A.; Fox, D.J.; Talati, A.; Pantea, C.; Brady, L.; Carter, S.L.; Friedenberg, E.; Vora, N.M.; Browne, M.L.; Lee, C.T. Prevalence and Clinical Attributes of Congenital Microcephaly-New York, 2013-2015. MMWR Morb. Mortal. Wkly. Rep. 2017, 66, 125-129. [CrossRef]

110. Cragan, J.D.; Isenburg, J.L.; Parker, S.E.; Alverson, C.J.; Meyer, R.E.; Stallings, E.B.; Kirby, R.S.; Lupo, P.J.; Liu, J.S.; Seagroves, A.; et al. Population-based microcephaly surveillance in the United States, 2009 to 2013: An analysis of potential sources of variation. Birth Defects Res. A Clin. Mol. Teratol. 2016, 106, 972-982. [CrossRef] [PubMed]

111. Mai, C.T.; Kucik, J.E.; Isenburg, J.; Feldkamp, M.L.; Marengo, L.K.; Bugenske, E.M.; Thorpe, P.G.; Jackson, J.M.; Correa, A.; Rickard, R.; et al. Selected birth defects data from population-based birth defects surveillance programs in the United States, 2006 to 2010: Featuring trisomy conditions. Birth Defects Res. A Clin. Mol. Teratol. 2013, 97, 709-725. [CrossRef] [PubMed]

112. Whelan, M.A. Practice parameter: Evaluation of the child with microcephaly (an evidence-based review): Report of the quality standards subcommittee of the American Academy of Neurology and the Practice Committee of the Child Neurology Society. Neurology 2010, 74, 1079, author reply 1079 (2010). [CrossRef]

113. Faheem, M.; Naseer, M.I.; Rasool, M.; Chaudhary, A.G.; Kumosani, T.A.; Ilyas, A.M.; Pushparaj, P.; Ahmed, F.; Algahtani, H.A.; Al-Qahtani, M.H.; et al. Molecular genetics of human primary microcephaly: An overview. BMC Med. Genomics 2015, 8 (Suppl. 1), S4. [CrossRef] [PubMed]

114. Ashwal, S.; Michelson, D.; Plawner, L.; Dobyns, W.B.; Quality Standards Subcommittee of the American Academy of Neurology. Practice parameter: Evaluation of the child with microcephaly (an evidence-based review)—report of the Quality Standards Subcommittee of the American Academy of Neurology and the Practice Committee of the Child Neurology Society. Neurology 2009, 73, 887-897. [CrossRef] 
115. Schwartz, D.A. Autopsy and Postmortem Studies Are Concordant: Pathology of Zika Virus Infection Is Neurotropic in Fetuses and Infants with Microcephaly Following Transplacental Transmission. Arch. Pathol. Lab. Med. 2017, 141, 68-72. [CrossRef] [PubMed]

116. van der Linden, V.; Pessoa, A.; Dobyns, W.; Barkovich, A.J.; Junior, H.V.; Filho, E.L.; Ribeiro, E.M.; Leal, M.C.; Coimbra, P.P.; Aragao, M.F.; et al. Description of 13 Infants Born during October 2015-January 2016 With Congenital Zika Virus Infection Without Microcephaly at Birth—Brazil. MMWR Morb. Mortal. Wkly. Rep. 2016, 65, 1343-1348. [CrossRef]

117. Mlakar, J.; Korva, M.; Tul, N.; Popovic, M.; Poljsak-Prijatelj, M.; Mraz, J.; Kolenc, M.; Resman Rus, K.; Vesnaver Vipotnik, T.; Fabjan Vodusek, V.; et al. Zika Virus Associated with Microcephaly. N. Engl. J. Med. 2016, 374, 951-958. [CrossRef] [PubMed]

118. Driggers, R.W.; Ho, C.Y.; Korhonen, E.M.; Kuivanen, S.; Jaaskelainen, A.J.; Smura, T.; Rosenberg, A.; Hill, D.A.; DeBiasi, R.L.; Vezina, G.; et al. Zika Virus Infection with Prolonged Maternal Viremia and Fetal Brain Abnormalities. N. Engl. J. Med. 2016. [CrossRef] [PubMed]

119. Rasmussen, S.A.; Jamieson, D.J.; Honein, M.A.; Petersen, L.R. Zika Virus and Birth Defects-Reviewing the Evidence for Causality. N. Engl. J. Med. 2016, 374, 1981-1987. [CrossRef]

120. Villamil-Gomez, W.E.; Mendoza-Guete, A.; Villalobos, E.; Gonzalez-Arismendy, E.; Uribe-Garcia, A.M.; Castellanos, J.E.; Rodriguez-Morales, A.J. Diagnosis, management and follow-up of pregnant women with Zika virus infection: A preliminary report of the ZIKERNCOL cohort study on Sincelejo, Colombia. Travel Med. Infect. Dis. 2016, 14, 155-158. [CrossRef]

121. Silva, N.M.; Santos, N.C.; Martins, I.C. Dengue and Zika Viruses: Epidemiological History, Potential Therapies, and Promising Vaccines. Trop. Med. Infect. Dis. 2020, 5, 150. [CrossRef]

122. Abrams, R.P.M.; Yasgar, A.; Teramoto, T.; Lee, M.H.; Dorjsuren, D.; Eastman, R.T.; Malik, N.; Zakharov, A.V.; Li, W.; Bachani, M.; et al. Therapeutic candidates for the Zika virus identified by a high-throughput screen for Zika protease inhibitors. Proc. Natl. Acad. Sci. USA 2020, 117, 31365-31375. [CrossRef]

123. Bouattour, A.; Khrouf, F.; Rhim, A.; M'Ghirbi, Y. First Detection of the Asian Tiger Mosquito, Aedes (Stegomyia) albopictus (Diptera: Culicidae), in Tunisia. J. Med. Entomol. 2019, 56, 1112-1115. [CrossRef]

124. Tsuzuki, A.; Vu, T.D.; Higa, Y.; Nguyen, T.Y.; Takagi, M. High potential risk of dengue transmission during the hot-dry season in Nha Trang City, Vietnam. Acta Trop. 2009, 111, 325-329. [CrossRef]

125. Bohers, C.; Mousson, L.; Madec, Y.; Vazeille, M.; Rhim, A.; M'Ghirbi, Y.; Bouattour, A.; Failloux, A.B. The recently introduced Aedes albopictus in Tunisia has the potential to transmit chikungunya, dengue and Zika viruses. PLoS Negl. Trop. Dis. 2020, 14, e0008475. [CrossRef]

126. Nakhapakorn, K.; Tripathi, N.K. An information value based analysis of physical and climatic factors affecting dengue fever and dengue haemorrhagic fever incidence. Int. J. Health Geogr. 2005. [CrossRef] [PubMed]

127. Alomar, A.A.; Eastmond, B.H.; Alto, B.W. The effects of exposure to pyriproxyfen and predation on Zika virus infection and transmission in Aedes aegypti. PLoS Negl. Trop. Dis. 2020, 14, e0008846. [CrossRef] [PubMed]

128. Acevedo-Garcia, D.; Lochner, K.A.; Osypuk, T.L.; Subramanian, S.V. Future directions in residential segregation and health research: A multilevel approach. Am. J. Public Health 2003, 93, 215-221. [CrossRef] [PubMed]

129. Power, G.M.; Francis, S.C.; Sanchez Clemente, N.; Vasconcelos, Z.; Brasil, P.; Nielsen-Saines, K.; Brickley, E.B.; Moreira, M.E. Examining the Association of Socioeconomic Position with Microcephaly and Delayed Childhood Neurodevelopment among Children with Prenatal Zika Virus Exposure. Viruses 2020, 12, 1342. [CrossRef] [PubMed]

130. Musoke, D.; Boynton, P.; Butler, C.; Musoke, M.B. Health seeking behaviour and challenges in utilising health facilities in Wakiso district, Uganda. Afr. Health Sci. 2014, 14, 1046-1055. [CrossRef] [PubMed]

131. Ryan, S.J.; Carlson, C.J.; Tesla, B.; Bonds, M.H.; Ngonghala, C.N.; Mordecai, E.A.; Johnson, L.R.; Murdock, C.C. Warming temperatures could expose more than 1.3 billion new people to Zika virus risk by 2050. Glob. Chang. Biol. 2020, 27, 84-93. [CrossRef]

132. Ryan, S.J.; Carlson, C.J.; Mordecai, E.A.; Johnson, L.R. Global expansion and redistribution of Aedes-borne virus transmission risk with climate change. PLoS Negl. Trop. Dis. 2019, 13, e0007213. [CrossRef] [PubMed] 